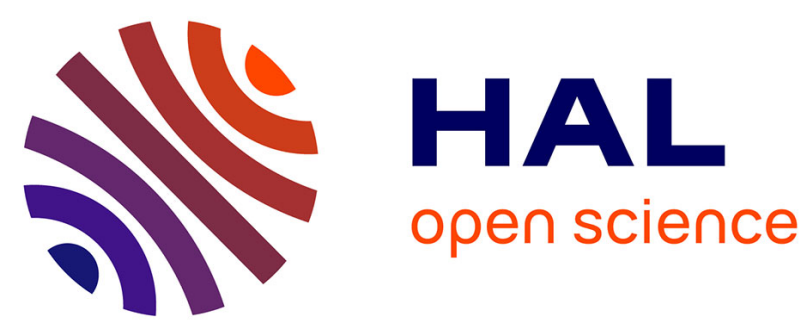

\title{
Airborne studies of aerosol emissions from savanna fires in southern Africa: 2. Aerosol chemical composition
}

M. Andreae, T. Andreae, H. Annegarn, J. Beer, H. Cachier, P. Le Canut, W. Elbert, W. Maenhaut, I. Salma, F. Wienhold, et al.

\section{- To cite this version:}

M. Andreae, T. Andreae, H. Annegarn, J. Beer, H. Cachier, et al.. Airborne studies of aerosol emissions from savanna fires in southern Africa: 2. Aerosol chemical composition. Journal of Geophysical Research: Atmospheres, 1998, 103 (D24), pp.32119-32128. 10.1029/98JD02280 . hal-03119603

\section{HAL Id: hal-03119603 \\ https://hal.science/hal-03119603}

Submitted on 25 Jan 2021

HAL is a multi-disciplinary open access archive for the deposit and dissemination of scientific research documents, whether they are published or not. The documents may come from teaching and research institutions in France or abroad, or from public or private research centers.
L'archive ouverte pluridisciplinaire HAL, est destinée au dépôt et à la diffusion de documents scientifiques de niveau recherche, publiés ou non, émanant des établissements d'enseignement et de recherche français ou étrangers, des laboratoires publics ou privés. 


\title{
Airborne studies of aerosol emissions from savanna fires in southern Africa: \\ 2. Aerosol chemical composition
}

\author{
M. O. Andreae, ${ }^{1}$ T. W. Andreae, ${ }^{1}$ H. Annegarn, ${ }^{2}$ J. Beer, ${ }^{2}$ H. Cachier, ${ }^{3}$ P. le Canut, ${ }^{1}$ \\ W. Elbert, ${ }^{1}$ W. Maenhaut, ${ }^{4}$ I. Salma, ${ }^{4,5}$ F. G. Wienhold, ${ }^{1}$ and T. Zenker ${ }^{1}$
}

\begin{abstract}
We investigated smoke emissions from fires in savanna, forest, and agricultural ecosystems by airborne sampling of plumes close to prescribed burns and incidental fires in southern Africa. Aerosol samples were collected on glass fiber filters and on stacked filter units, consisting of a Nuclepore prefilter for particles larger than $\sim 1-2 \mu \mathrm{m}$ and a Teflon second filter stage for the submicron fraction. The samples were analyzed for soluble ionic components, organic carbon, and black carbon. Onboard the research aircraft, particle number and volume distributions as a function of size were determined with a laser-optical particle counter and the black carbon content of the aerosol with an aethalometer. We determined the emission ratios (relative to $\mathrm{CO}_{2}$ and $\mathrm{CO}$ ) and emission factors (relative to the amount of biomass burnt) for the various aerosol constituents. The smoke aerosols were rich in organic and black carbon, the latter representing 10-30\% of the aerosol mass. $\mathrm{K}^{+}$and $\mathrm{NH}_{4}^{+}$were the dominant cationic species in the smoke of most fires, while $\mathrm{Cl}^{-}$and $\mathrm{SO}_{4}^{2-}$ were the most important anions. The aerosols were unusually rich in $\mathrm{Cl}^{-}$, probably due to the high $\mathrm{Cl}$ content of the semiarid vegetation. Comparison of the element budget of the fuel before and after the fires shows that the fraction of the elements released during combustion is highly variable between elements. In the case of the halogen elements, almost the entire amount released during the fire is present in the aerosol phase, while in the case of $\mathrm{C}, \mathrm{N}$, and $\mathrm{S}$, only a small proportion ends up as particulate matter. This suggests that the latter elements are present predominantly as gaseous species in the fresh fire plumes studied here.
\end{abstract}

\section{Introduction}

Smoke from large vegetation fires is one of the most conspicuous impacts of human activity on the atmospheric environment. For example, smoke plumes from savanna and forest fires are frequently seen even from spacecraft orbiting some $400 \mathrm{~km}$ above the Earth. [Andreae, 1993a]. Recent estimates suggest that pyrogenic aerosol emissions may be the second largest source of anthropogenic aerosols after the production of sulfates from $\mathrm{SO}_{2}$ [Andreae, 1995; Andreae et al., 1996a; Houghton et al., 1996; Liousse et al., 1996]. Since the man-made emission of aerosols has been implicated in global climate change [Charlson et al., 1987, 1992; Houghton et al., 1996], research on their origins, properties, and long-range transport has intensified in recent years. The climatic effect of aerosols depends on their abundance, size distribution, optical properties (especially the light absorption capacity [Hansen et al., 1997]), solubility, and spatial distri-

\footnotetext{
'Biogeochemistry and Air Chemistry Departments, Max Planck Institute for Chemistry, Mainz, Germany.

${ }^{2}$ University of Witwatersrand, Johannesburg, South Africa.

${ }^{3}$ Centre des Faibles Radioactivités, CNRS-CEA, Gif-sur-Yvette, France.

${ }^{4}$ Institute for Nuclear Sciences, University of Gent, Gent, Belgium.

${ }^{5}$ KFKI Atomic Research Institute, Budapest, Hungary
}

Copynght 1998 by the Amencan Geophysical Union.

Paper number 985D02280.

0148-0227/98ID-02280\$09.00 bution. Smoke aerosols can influence climate by the ,direct" effect, through the scattering of incident sunlight, and by the ,indirect" effect through the modification of cloud properties, since both the inorganic and the organic components of biomass smoke are watersoluble [Novakov and Corrigan, 1996]. Furthermore, the role of aerosols in atmospheric chemistry has lately received increased attention [Andreae and Crutzen, 1997]. Because savanna fires are the single largest source of biomass burning emissions worldwide, ranking ahead of forest fires, agricultural fires, or domestic burning [Andreae, 1993b; Hao and Liu, 1994], an investigation on the aerosol emission characteristics from these fires was given high priority within the IGAC/BIBEX (International Global Atmospheric Chemistry Program/Biomass Burning Experiment) operational plan [Pszenny and Prinn, 1994].

Despite the importance of savanna fires to atmospheric chemistry and climate on both regional and global scales, there are still only a relatively small number of studies on the chemical and physical characteristics of the particulate emissions from these fires. Aerosol mass emission factors were determined during the Biomass Burning Airborne and Spaceborne Experiment (BASE) from cerrado fires in Brazil [Ward et al., 1991, 1992], but the chemical composition of the aerosol was not analyzed. The ionic composition of smoke from cerrado fires was described by Allen and Miguel [1995]. The first measurements on aerosol emissions from African savanna fires were made in West Africa in the course of the FOS/DECAFE-91 (Fire of Savannas/Dynamique et Chimie Atmosphérique en Forêt Equatoriale) experiment, which took place in the humid savanna of Côte d'Ivoire, West Africa [Cachier et al., 1995; Echalar et al., 1995; Gaudichet et al., 1995; Lacaux et al., 1995]. 
The determination of aerosol composition, size distribution, and emission ratios from savanna fires in southern Africa was an important goal of the international measurement campaign SAFARI-92 (Southem Africa Fire/Atmosphere Research Initiative), a component of the IGAC/BIBEX project STARE (Southern Tropical Atlantic Region Experiment) [Andreae et al., 1994, 1996b], which took place during the 1992 dry season (AugustOctober). During SAFARI-92, aerosols emitted from various fires were analyzed for a variety of chemical and physical properties. The size distribution was investigated from aircraft with a laseroptical aerosol probe [Le Canut et al., 1996b], while at ground level, the aerosol mass concentration was determined using an optical system [Cachier et al., 1996] and by weighing filters [Maenhaut et al., 1996; Ward et al., 1996]. Also at ground level, the organic and black carbon content of the aerosols was determined by optical [Maenhaut et al., 1996] and thermochemical [Cachier et al., 1996] methods. The chemical composition of the aerosol was investigated using particle-induced X-ray emission (PIXE) and instrumental neutron activation analysis (INAA) by Maenhaut et al.[1996]. During TRACE-A (Transport and Atmospheric Chemistry near the Equator - Atlantic), the sister experiment to SAFARI-92, aerosol chemical composition and size distribution were measured over savanna and forest fires in Brazil [Pereira et al., 1996]. More recently, a considerable body of data on pyrogenic aerosols from the Brazilian savannas has been obtained during the SCAR-B (Smoke, Clouds, and Radiation - Brazil) campaign [Kaufman et al., this issue].

In this paper, we present data on the chemical composition of the pyrogenic aerosols from the fires encountered by the DC-3 aircraft during SAFARI-92, and give emission ratios and emission factors for various chemical species in these aerosols. The number and volume size distributions of the smoke particles and the corresponding emission factors have been discussed in a companion paper [Le Canut et al., 1996b]. The results from the ground-based aerosol measurements have been reported previously [Cachier et al., 1996; Maenhaut et al., 1996].

\section{Methods}

The aerosol sampling system consisted of an isokinetic inlet directly coupled to a stacked filter unit. We utilized a thin-walled inlet nozzle with a curved leading edge; the design is based on criteria for aircraft engine intakes at low Mach numbers [Andreae et al., 1988a]. This design avoids distortion of the pressure field at the nozzle tip and the resulting problems associated with flow separation and turbulence. Aerosol samples for the determination of soluble ionic constituents were collected using two-stage stacked filter holders ( $90 \mathrm{~mm}$ diameter) containing either a filter pair for size-segregated sampling or a single glass fiber filter. When the stacked filter pairs were used, the coarse fraction $(\geq 1.2$ $\mu \mathrm{m}$ diameter) of the aerosol was collected on the first filter stage, which consisted of a Nuclepore filter (Nuclepore Corporation, Pleasanton, California; nominal pore size $5.0 \mu \mathrm{m}$; $50 \%$ cutoff diameter at the face velocity used: $\sim 1.2 \mu \mathrm{m}$ [John et al., 1983]). The fine fraction, which had passed through the Nuclepore filter, was collected on a Zefluor membrane filter (Gelman Sciences Inc., Ann Arbor, Michigan; nominal pore size $1.0 \mu \mathrm{m}$ ) with a collection efficiency $>99.9 \%$ for particles down to $0.03 \mu \mathrm{m}$ diameter. The glass fiber filters (type AE; Gelman Sciences Inc., Ann Arbor) were precleaned by heating to $550{ }^{\circ} \mathrm{C}$ for 1 hour. Flow rates and sample volumes were measured with an orifice flowmeter, which had been calibrated using an integrating mass flowmeter (Teledyne Hastings-Raydist, Hampton, Virginia). The exposed filters were cut up and the pieces transferred to polyethylene vials. The Nuclepore filters were extracted with $10 \mathrm{~mL}$ of deionized water, the Zefluor filters were first wetted with $1 \mathrm{~mL}$ methanol, then $9 \mathrm{~mL}$ of deionized water was added. For the analysis of the aerosol on the glass fiber filters, subsamples with a diameter of $16.2 \mathrm{~mm}$ were cut out with a punch and extracted with a mixture of $1 \mathrm{~mL}$ methanol, $4 \mathrm{~mL}$ deionized water, and 50 $\mu \mathrm{L}$ chloroform. The dissolved ionic species in the extracts were determined by capillary zone electrophoresis (CZE) [Beck and Engelhardt, 1992]. Detection limits of about $2 \mu \mathrm{mol} \mathrm{L}^{-1}$ (signalto-noise ratio $=3$ ) were obtained and the overall precision of individual determinations was better than $5 \%$.

For the determination of particulate and black carbon, samples were collected on precombusted Whatman GF/F glass fiber filters (47 mm diameter) mounted in polycarbonate holders. Particulate and black carbon were determined by combustion analysis; details are reported by Cachier et al. [1996]. The sample airstream for the glass fiber filters was taken from the same inlet as used for the high-volume stacked filters. In addition, the black carbon (BC) (also called elemental carbon or soot carbon) concentration was monitored continuously with an airborne aethalometer (Magee Scientific, Berkeley, California). This instrument measures the light absorption by aerosol deposited on a glass fiber filter through which sample air is pumped at a flow rate of $\sim 20 \mathrm{lpm}$; the $\mathrm{BC}$ concentration is determined from the increase of light absorption over a specified time interval. We recorded the data at 2 min intervals; with this averaging period the precision of the instrument varied between 80 and $250 \mathrm{ng} \mathrm{m}^{-3}$, depending on operating conditions (e.g., filter loading, flow variations, etc.). Liousse et al. [1993] have shown that the specific attenuation cross section, which is used to convert the light absorption measured by the instrument into $\mathrm{BC}$ concentration, varies between 5 and 20 $\mathrm{m}^{2} \cdot \mathrm{g}^{-1}$ in different sampling environments. We determined the specific attenuation cross section on our samples by analyzing the aethalometer filters by the same thermochemical procedure as was used for the filter samples discussed above. The observed values for the attenuation cross section ranged from 8.1 to $19.3 \mathrm{~m}^{2} \mathrm{~g}^{-1}$, with the freshest smoke showing the highest values in agreement with the observations of Liousse et al. [1993]. For each flight, the cross section measured on the aethalometer filter from the same flight was used to calculate $\mathrm{BC}$ concentrations.

$\mathrm{CO}_{2}$ and $\mathrm{CO}$ were measured on the aircraft for plume detection and as reference species for the calculation of emission ratios. The $\mathrm{CO}_{2}$ instrument was a nondispersive infrared gas analyzer (LI-COR Corp., Lincoln, Nebraska) operating with an internal time constant of $10 \mathrm{~s}$ [Zenker et al., 1996]. The CO instrument was a tunable diode laser spectrometer (TDLS) using the twotone frequency modulation technique, recording data at intervals of $1 \mathrm{~s}$.

The aerosol concentrations were corrected to standard temperature and pressure (STP) $\left(T=20^{\circ} \mathrm{C}, P=1013.25 \mathrm{hPa}\right)$ and are given as particles per cubic centimeter $\left(\mathrm{cm}^{-3}\right)$. Aerosol emission ratios are expressed as mole ratios relative to $\mathrm{CO}_{2}$ or $\mathrm{CO}$ (corrected for ambient concentrations), for example,

$$
\mathrm{ERC} / \mathrm{CO}_{2}=\frac{\Delta \mathrm{Cl}}{\Delta \mathrm{CO}_{2}}=\frac{[\mathrm{Cl}]_{\text {smoke }}-[\mathrm{Cl}]_{\text {ambient }}}{\left[\mathrm{CO}_{2}\right]_{\text {smoke }}-\left[\mathrm{CO}_{2}\right]_{\text {ambient }}}
$$

For the determination of the ambient background concentrations we used measurements taken in the sampling region before or after the plume sampling. The background concentrations were 
first subtracted from both trace and reference species concentration data. Then, the concentration of the reference gas anomaly (i.e., the concentration after background subtraction) was integrated over the same period over which the trace species sample had been collected. The emission ratio was then calculated as the ratio between the integrated trace and the reference species anomalies. The various techniques for these calculations and the associated errors are discussed by Le Canut et al. [1996b].

From these emission ratios we derived emission factors, i.e., the amount of a substance emitted per amount of fuel consumed ( $\mathrm{g} \mathrm{kg}^{-1}$ dry matter $(\mathrm{dm})$ ). Calculation of this value requires knowledge of the carbon content of the biomass burned and the carbon budget of the fire usually expressed as combustion efficiency [see Ward et al., 1996]; both parameters are difficult to determine in the field, as opposed to laboratory experiments where they are readily established. During SAFARI-92 the composition of the biomass and the amounts of fuel consumed were determined at the burn plots in Kruger Park, at the four sites in Zambia where ground studies were conducted, and in the sugar cane fields in Swaziland. The mean carbon content of the African savanna fuels (consisting mostly of grass and litter) was found to be $47 \%$ [Susott et al., 1996]. From this value and from the trace gas emission ratios measured during SAFARI-92, a mean $\mathrm{CO}_{2}$ emission factor of $1600 \mathrm{~g} \mathrm{CO}_{2} \mathrm{~kg}^{-1} \mathrm{dm}$ (dry mass) is obtained [Andreae et al., 1996a; Cofer et al., 1996; Ward et al., 1996]. Aerosol species emission factors were then calculated by multiplying the aerosol species emission ratio (after conversion to mass units [g species $\left.\mathrm{kg}^{-1} \mathrm{CO}_{2}\right]$ ) with the $\mathrm{CO}_{2}$ emission factor of $1600 \mathrm{~g} \mathrm{CO}_{2} \mathrm{~kg}^{-1} \mathrm{dm}$.

Detailed analyses by INAA were made on 12 samples of savanna fuels and 8 samples of combustion residues. The INAA involved two separate irradiations (one of $5 \mathrm{~min}$ and one of 7 hours) of a $150 \mathrm{mg}$ fraction of each sample at a thermal neutron flux of $2-3 \times 10^{12} \mathrm{n} \mathrm{cm}^{-2} \mathrm{~s}^{-1}$ in the Thetis reactor of the University of Gent. After each irradiation, two or three gamma spectrometric measurements were carried out with a high-resolution $\mathrm{Ge}$ detector. The counting procedures, analyte radioisotopes, and photopeak area integration methods were similar to those described by Schutyser et al. [1978]. The quantification was performed by comparison with multielement standards, which were prepared by pipetting solutions of the analyte elements onto Whatman filter paper. Up to 39 elements were measured by INAA, i.e., $\mathrm{Na}, \mathrm{Mg}$, $\mathrm{Al}, \mathrm{Cl}, \mathrm{K}, \mathrm{Ca}, \mathrm{Sc}, \mathrm{Ti}, \mathrm{V}, \mathrm{Cr}, \mathrm{Mn}, \mathrm{Fe}, \mathrm{Co}, \mathrm{Ni}, \mathrm{Cu}, \mathrm{Zn}, \mathrm{Ga}, \mathrm{As}, \mathrm{Se}$, $\mathrm{Br}, \mathrm{Rb}, \mathrm{Sr}, \mathrm{Mo}, \mathrm{Ag}, \mathrm{Cd}$, In, Sn, Sb, I, Cs, Ba, La, Ce, Sm, Eu, Lu, $\mathrm{W}, \mathrm{Au}$, and $\mathrm{Th}$.

\section{Results and Discussion}

\subsection{Study Sites}

Emission information was derived from smoke samples collected directly over experimental fires, or over fires encountered during regional survey flights in the study area, which extended from Swaziland across South Africa, Zimbabwe, and Zambia to southeastern Angola. The location of the flight tracks and study sites is shown in Figure 1. Experimental fires for SAFARI-92 were conducted in Kruger National Park (KNP), South Africa, and in sugar cane fields near Big Bend, Swaziland. The KNP study sites were in a low-fertility, moist "sourveld" savanna at Pretoriuskop, near the southern end of the park. This vegetation is relatively nutrient poor and had not been intensively grazed in spite of the severe drought that had prevailed in southern Africa for 2 years when SAFARI-92 began. Information on the vegetation characteristics and fire behavior can be found in papers by Trollope et al. [1996], Shea et al. [1996], and Stocks et al. [1996]. The two fires studied using the DC-3 aircraft were set on large management blocks in KNP (55 and 56, with areas of 2043 and 2333 ha, respectively).

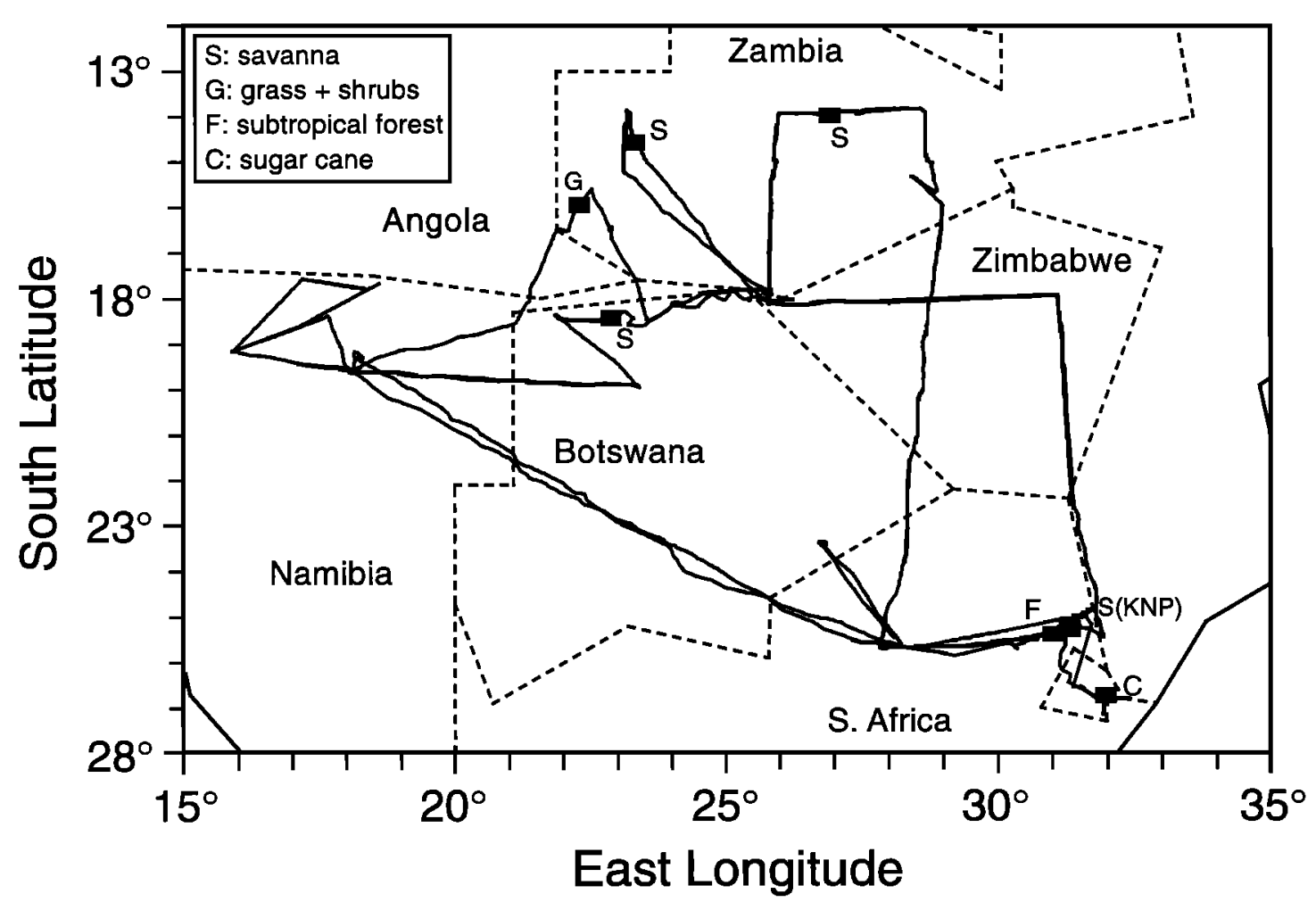

Figure 1. Map of the study region with flight tracks for the SAFARI-92 campaign and sampling sites for the chemical characterization of smoke aerosols. 
The sugar cane fires sampled by the DC- 3 represent burns that are typical of regional agricultural practices. Such fires are set immediately before harvesting in order to facilitate the cutting and processing of the sugar cane. This practice results in substantial levels of air pollution in many sugar-growing areas [Kirchhoff et al., 1991]. In South Africa, the largest sugar cane growing country in the region, we estimate, based on our emission factors and the Food and Agriculture Organization (FAO) production statistics, that about 14,000 tons of aerosols ( $<3 \mu \mathrm{m}$ diameter) are emitted from sugar cane burning annually. During SAFARI-92, emissions from fires on two sugar cane fields of 12 and 43.7 ha area were investigated. These fields were located near Big Bend, Swaziland, and had been scheduled to be burned on the day of the study based on standard agricultural criteria. The fires burned very intensively with large flames and consumed about 25 tons of dry mass per hectare.

On its survey and transit flights the DC-3 sampled numerous „fires of opportunity." We studied two groups of wildfires in the Drakensberg Escarpment of South Africa, where mixtures of native forest, shrub, and grass were burning. A large number of fires were observed and sampled in the savannas of Zambia, Botswana, and Angola. These fires represent native burning practices in grasslands and savannas, which typically consist of relatively small and well-controlled fires. They frequently burn in the form of backfires, i.e., with the fire front moving against the prevailing wind direction; details are given in the article by Le Canut et al. [1996b]. Unfortunately, most of these fires were relatively small, and the aircraft was not able to remain in their smoke plumes long enough to allow the accumulation of a sample large enough for the determination of the chemical composition of the aerosols. Only during flights SAF05 (native forest and shrub in the Drakensberg Range) and SAF14 (savanna fires in central Zambia) did we succeed in accumulating a filter sample by flying repeated passes through the plumes of such „fires of opportunity“. For the remaining cases, only the $\mathrm{BC}$ data from the aethalometer are available.

\subsection{Black Carbon and Total Carbon}

Carbonaceous aerosol, consisting of organic carbon and black carbon, is a by-product of the incomplete combustion of both fossil fuels and biomass and is therefore a ubiquitous component of anthropogenic aerosols. The sum of organic and black carbon aerosol concentrations is called total carbon, $\mathrm{C}_{t}$. BC is produced especially under intensely flaming conditions, when the supply of oxygen is deficient or when parts of a flame are quenched before the oxidation of carbon radicals is complete. Under smoldering conditions, on the other hand, little BC is produced, and the carbonaceous fraction of the aerosol consists predominantly of tarry materials. Since flaming conditions dominate over smoldering conditions in savanna fires, a relatively high BC content is expected in their smoke emissions.

We determined the $\mathrm{BC}$ emission factors $\left(\mathrm{EF}_{\mathrm{BC}}\right)$ from savanna, grassland, forest, and sugar cane fires in southern Africa based on continuous measurements of the concentrations of $\mathrm{BC}$ and $\mathrm{CO}_{2}$ made during flights through fire plumes (Table 1). The emission factors from individual fires varied between 0.26 and $0.91 \mathrm{~g} \mathrm{BC} \mathrm{kg}^{-1} \mathrm{dm}$. The lowest values were found for the Drakensberg forest fires, where a high $\mathrm{CO} / \mathrm{CO}_{2}$ emission ratio (0.094) [Andreae et al., 1996a] showed smoldering combustion to be a substantial component. The mean $\mathrm{EF}_{\mathrm{BC}}$ for the savanna and grassland fires is $0.59 \pm 0.19 \mathrm{~g} \mathrm{BC} \mathrm{kg}^{-1} \mathrm{dm}$, a value almost identical to the one measured over the sugar cane fires $\left(0.61 \pm 0.18 \mathrm{~g} \mathrm{BC} \mathrm{kg}^{-1} \mathrm{dm}\right)$. The KNP fires had the lowest $\mathrm{EF}_{\mathrm{BC}}$ values of the savanna fires, while the highest values were found over the relatively small savanna fires in Zambia. Because of the difficulty of obtaining samples large enough for carbon analysis during the short transits through the smoke plumes, an emission

Table 1. Emission Factors (in $\mathrm{g} \mathrm{kg}^{-1} \mathrm{dm}$ ) for Black Carbon (BC), Total Carbon $\left(\mathrm{C}_{t}\right.$ ), and Particulate Matter $<3.0 \mu \mathrm{m}$ $\left(\mathrm{PM}_{3.0}\right)$ for Vegetation Fires in Southern Africa and Black Carbon Content of Aerosol ( $\left.\mathrm{PM}_{3.0}\right)$

\begin{tabular}{|c|c|c|c|c|c|c|}
\hline Ecosystem/Flight & $N$ & $\begin{array}{r}E F_{\mathrm{BC}} \\
\mathrm{g} \mathrm{kg}^{-1} \mathrm{~d} \\
\end{array}$ & s.d. & $\begin{array}{c}\mathrm{EF}_{\mathrm{a}} \\
\mathrm{g} \mathrm{kg}^{-1} \mathrm{dm}\end{array}$ & $\begin{array}{c}\mathrm{EF}_{\mathrm{PM} 3,0} \\
\mathrm{~g} \mathrm{~kg}^{-1} \mathrm{dm}\end{array}$ & $\begin{array}{c}\text { BC } \\
\% \\
\end{array}$ \\
\hline \multicolumn{7}{|c|}{ Subtropical Forest (Drakensberg) } \\
\hline SAF03 & 1 & 0.26 & $\cdots$ & - & - & -- \\
\hline SAF05 & 7 & 0.28 & 0.13 & - & -- & $\cdots$ \\
\hline Average & & 0.27 & -- & -- & -- & $\cdots$ \\
\hline \multicolumn{7}{|c|}{ Sugar Cane Fields } \\
\hline SAF04 (Swaziland) & 2 & 0.61 & 0.18 & -- & 3.9 & 15 \\
\hline \multicolumn{7}{|c|}{ Tropical Savanna and Grassland } \\
\hline SAF03 (KNP block 56) & 3 & 0.44 & 0.10 & $\cdots$ & -- & --- \\
\hline SAF06 (KNP block 55) & 13 & 0.41 & 0.10 & 2.2 & 4.1 & 10 \\
\hline SAF08 (savanna, W. Zambia) & 1 & 0.48 & -- & -- & -- & --- \\
\hline SAF09 (savanna, Namibia) & 1 & 0.74 & - & -- & 2.8 & 26 \\
\hline SAF14 (savanna, central Zambia) & 3 & 0.91 & 0.39 & --- & 3.4 & 27 \\
\hline SAF15 (grassland, W. Zambia) & 1 & 0.62 & - & -- & 2.2 & 27 \\
\hline Average & & 0.59 & 0.19 & 2.2 & 3.1 & 19 \\
\hline
\end{tabular}

The number of plume passes analyzed is indicated $(N)$. 
factor for $\mathrm{C}_{t}$ could only be obtained from the fire on KNP block 55: $2.2 \mathrm{~g} \mathrm{C} \mathrm{kg}^{-1} \mathrm{dm}$.

The BC content of the smoke aerosols can be estimated from the $\mathrm{BC}$ emission factors together with independently obtained aerosol mass emission factors. Mass emission factors for the aerosol size range $0.12-3.0 \mu \mathrm{m}$ diameter $\left(\mathrm{EF}_{\mathrm{PM} 3.0}\right)$ were obtained from measurements with a laser-optical aerosol probe (PCASP-100X) [Le Canut et al., 1996b]. The $\mathrm{EF}_{\mathrm{PM} 3.0}$ values (Table 1) range from 2.2 to $4.1 \mathrm{~g} \mathrm{~kg}^{-1} \mathrm{dm}$, assuming a density of $1.4 \mathrm{~g} \mathrm{~cm}^{-3}$ for the aerosol particles. This density was chosen to reflect the composition of the aerosol which consists predominantly of partially oxidized organic compounds with a density of about $1.2 \mathrm{~g} \mathrm{~cm}^{-3}$, with an admixture of sulfates and mineral matter with densities of 1.7-2.0 $\mathrm{g} \mathrm{cm}^{-3}$ [Le Canut et al., 1996a]. Our $\mathrm{EF}_{\mathrm{PM} 30}$ results are lower than the $\mathrm{EF}_{\mathrm{PM}}$ measurement made at ground level at $\mathrm{KNP}$ : Cachier et al. [1996] give a mean value of $9.7 \mathrm{~g} \mathrm{~kg}^{-1} \mathrm{dm}$ for the total particulate matter emission factor $\left(\mathrm{EF}_{\mathrm{TPM}}\right)$; at a fine fraction of $80 \%$ this corresponds to an $\mathrm{EF}_{\mathrm{PM} 2.0}$ of $7.8 \mathrm{~g} \mathrm{~kg}^{-1} \mathrm{dm}$. Ward et al.[1996] obtain an average $\mathrm{EF}_{\mathrm{PM} 2.5}$ value of $8.0 \pm 2.5 \mathrm{~g} \mathrm{~kg}^{-1} \mathrm{dm}$ for the large KNP fires. A similar difference is seen for $\mathrm{EF}_{\mathrm{C}}$, where the ground-based measurements gave a value of 6.4 and the airborne measurements of $2.2 \mathrm{~g} \mathrm{C} \mathrm{kg}^{-1} \mathrm{dm}$.

The reasons for this discrepancy of more than a factor of 2 are not clear. Differences in the measurement methodology (weighing filters versus the laser-optical probe) may play a role, but real differences between ground-level and airborne measurements cannot be excluded. Some of the organic compounds that make up the bulk of the aerosol may re-evaporate as the smoke becomes more dilute and their partial pressure in the gas phase is reduced. Some support for this hypothesis comes from the work of Liousse et al. [1995], who found that the relative percentage of $\mathrm{BC}$ in pyrogenic aerosols increased by almost $50 \%$ with the age of the plume over a time span of less than $5 \mathrm{~min}$.

The BC content of the smoke aerosols in the size fraction up to $3.0 \mu \mathrm{m}$ varies from 10 to $27 \%$ in the savanna and grassland fires, with the KNP fire providing the lowest value. The sugar cane fire produced smoke with $15 \% \mathrm{BC}$. Such high BC contents are consistent with the dark color of the smoke observed visually over the sugar cane fires and some of the savanna fires, especially during flight SAF15. Further independent support for the validity of the high $\mathrm{BC}$ contents of the savanna smokes comes from the measurements made on glass fiber filter samples collected over the KNP and sugar cane fires. The ratio $\mathrm{BC} / \mathrm{C}_{t}$ over the $\mathrm{KNP}$ fire (SAF06, block 55) was 20.4\%; given the $\mathrm{C}_{\text {/ }}$ TPM ratio of 0.43 measured for the KNP fires [Cachier et al., 1996], this corresponds to a $\mathrm{BC}$ content of $8.8 \%$, which is nearly identical to the $10 \%$ obtained from the aethalometer and PCASP-100X data. Higher $\mathrm{BC}$ contents were found in the smoke from several KNP fires by Maenhaut et al. [1996], who measured averages of 28 and $9.4 \% \mathrm{BC}$ in the fine fraction of smoke from the flaming and smoldering phases of combustion, respectively.

For the sugar cane fires, $\mathrm{BC} / \mathrm{C}_{t}$ on the glass fiber filters was found to be $26.2 \%$. No C, /TPM data are available for this fire, but using the value of about $60 \%$ frequently given in the literature [Andreae et al., 1988b; Ward et al., 1991; Andreae, 1993b; Cachier et al., 1996], we estimate a BC content of $16 \%$. Again, this value is close to the $15 \%$ obtained from the aethalometer and PCASP-100X data from this fire. It also agrees well with the value of $15 \%$ obtained in laboratory combustion experiments with sugar cane waste [Turn et al., 1997].

On the basis of mutually consistent measurements with the aethalometer, PCASP-100X probe, and filter samples on the DC-
3 aircraft and considering data from the smoke plumes as well as the regional aerosol during the fire season, we conclude that savanna and grassland fires are efficient emitters of black carbon, with $\mathrm{EF}_{\mathrm{BC}}$ of $0.6 \pm 0.2 \mathrm{~g} \mathrm{~kg}^{-1} \mathrm{dm}$. Our emission factors for $\mathrm{BC}$ are in good agreement with measurements made in the West African savanna $\left(\mathrm{EF}_{\mathrm{BC}}=0.52 \mathrm{~g} \mathrm{~kg}^{-1} \mathrm{dm}\right.$ [Cachier et al., 1996]), in the Brazilian cerrado $\left(\mathrm{EF}_{\mathrm{BC}}=0.72 \mathrm{~g} \mathrm{~kg}^{-1} \mathrm{dm}\right.$ for grassland and $0.45-0.72$ $\mathrm{g} \mathrm{kg}^{-1} \mathrm{dm}$ for savanna fires [Ferek et al., this issue]), and in laboratory combustion studies with grassy and herbaceous fuels $\left(E_{\mathrm{BC}}=0.75 \mathrm{~g} \mathrm{~kg}^{-1} \mathrm{dm}\right.$ [Turn et al., 1997]).

Given these $\mathrm{EF}_{\mathrm{BC}}$ values and the relatively low $\mathrm{PM}$ emission factors near $3 \mathrm{~g} \mathrm{~kg}^{-1} \mathrm{dm}$ observed from our fires, we conclude that a highly absorbing aerosol with a $\mathrm{BC}$ content of $10-30 \%$ is emitted. Our overall average value for the $\mathrm{BC}$ content $(19 \%)$ is higher by about a factor of 2 than the measurements made at KNP both by Cachier et al., [1996] and in this study, suggesting that the smoke from the KNP fires is unusually low in BC in comparison with other savanna fires studied here. The higher values found by Maenhaut et al. [1996] at KNP, especially in the flaming phase, may be related either to variability between different parts of the fire or to the fact that his values referred to the fine fraction only. In smoke from fires in the Brazilian cerrado, BC contents of 8$13 \%$ were found, values that are near the lower end of our range [Echalar et al., this issue, Reid et al., this issue]. BC contents similar to those observed by us were measured in a wind tunnel combustion experiment, where grassy and herbaceous fuels produced aerosols with a mean of $18 \% \mathrm{BC}$ and tree prunings yielded an average BC content of $22 \%$ [Turn et al., 1997]. We conclude that the dry conditions prevailing during SAFARI-92 led to burning conditions favoring efficient, flaming combustion and high fire temperatures, which produce low total aerosol yields. This, together with the fact that the emission factor for BC changes little with combustion efficiency [Ward et al., 1992; Ferek et al., this issue] explains why a highly absorbing aerosol rich in black carbon was produced by the fires investigated during our experiment.

The high BC content measured in the savanna smoke plumes is reflected in high $\mathrm{BC}$ concentrations in the regional aerosol over southern Africa during the fire season. For example, the $\mathrm{BC} / \mathrm{C}_{t^{-}}$ ratio measured in the regional background aerosol sample collected during flight SAF07 from KNP to Harare, Zimbabwe, was $21 \%$, corresponding to an approximate BC content of $13 \%$. The aethalometer and PCASP-100X data from the same flight give a $\mathrm{BC} / \mathrm{PM}_{30}$ ratio of $11-18 \%$, in reasonable agreement with the filter sample results. Trace gas and trajectory data show that the lower troposphere during the time period of this flight was filled with air masses polluted with smoke from biomass burning [Garstang et al., 1996; Maenhaut et al., 1996; Thompson et al., 1996; Zenker et al., 1996; M. O. Andreae et al., manuscript in preparation, 1998; G. A. Kirkman et al., manuscript in preparation, 1998]. For the entire series of flights made in late September over southern Africa (SAF07 to SAF11) the mean $\mathrm{BC} / \mathrm{C}_{t}$ ratio was $24 \%$, similar to measurements made in the smoke-filled air over western Africa during the fire season [Cachier et al., 1995].

\subsection{Soluble Ionic Species}

We measured the concentrations of the following soluble ionic species in the aerosol samples: the four anions, chloride, nitrate, sulfate, and oxalate, plus the five cations, ammonium, potassium, sodium, calcium, and magnesium. The results for the samples collected over the sugar cane fires and the KNP savanna fires are shown in Figure 2. Since the filter samples contain background as 

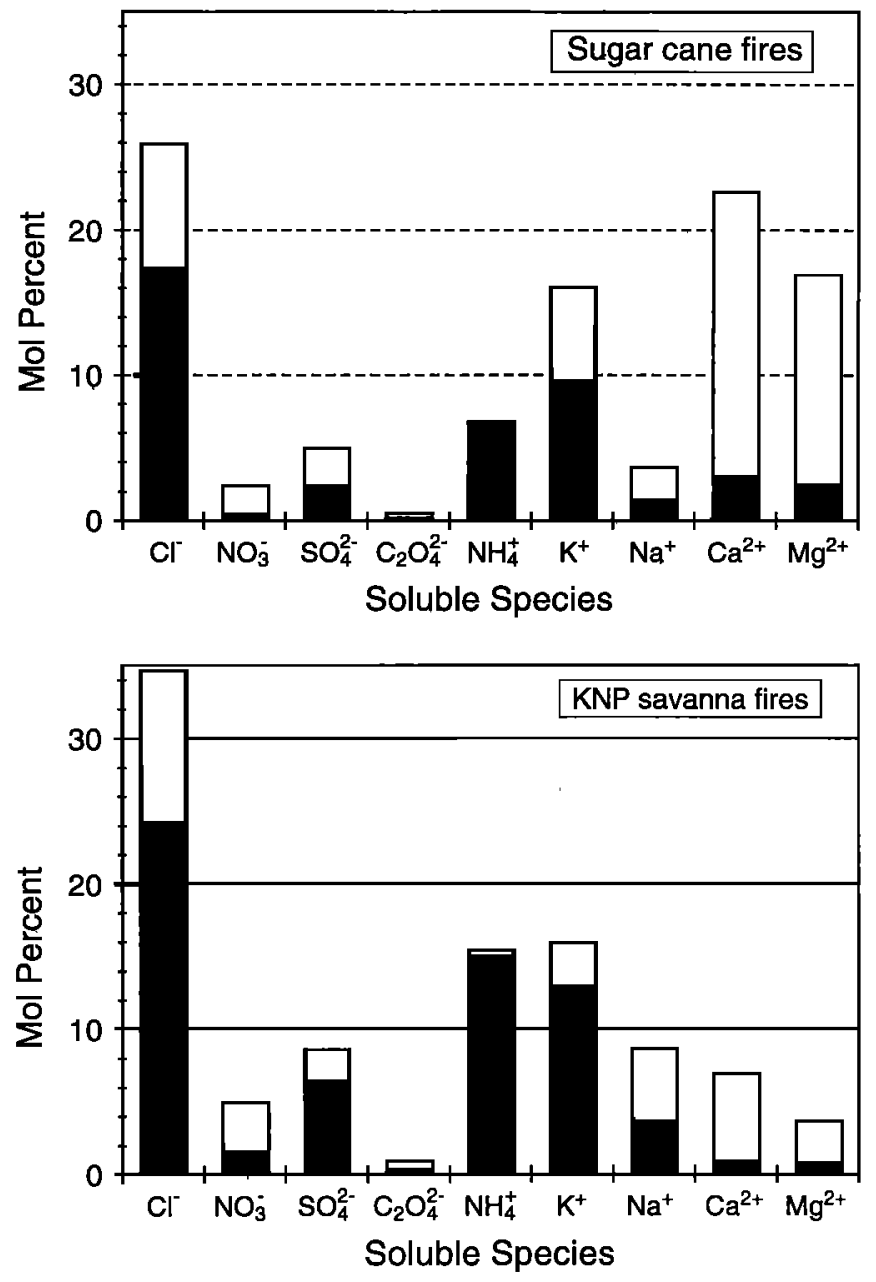

Figure 2. Composition of the soluble ionic fraction of smoke aerosols from (a) sugar cane burns and (b) KNP savanna fires. The fine fraction is indicated by a stippled pattern, the coarse fraction by the open part of the bars.

well as smoke aerosol, the regional background measured outside of the fires was subtracted to obtain the smoke component. The data are represented as percentages of the total soluble ionic species content of the smoke. It is evident that chloride, present both in the fine and in the coarse fractions, is the dominant anion, followed by sulfate. Nitrate is mostly present in the coarse fraction, suggesting that it originates from the deposition of $\mathrm{HNO}_{3}$ on mineral dust acrosol [Cachier et al., 1991]. Oxalate, a species typically observed in biomass smoke, was detectable in most samples but made only a minor contribution to the anion sum. Phosphate could not be measured in our samples.

The cation budget in the fine fraction is dominated to about equal parts by $\mathrm{K}^{+}$and $\mathrm{NH}_{4}^{+}$, both species typically present at elevated concentrations in the submicron fraction of pyrogenic aerosols [Andreae, 1983; Andreae et al., 1988b]. Large amounts of $\mathrm{Ca}^{2+}$ and $\mathrm{Mg}^{2+}$ were found in the coarse fraction of the sugar cane fire emissions, probably due to entrainment of soil dust due to the turbulence associated with the very intensive combustion typical of these fires. The emission factors for the soluble ionic species are given in Table 2.

Potassium is a highly useful tracer for pyrogenic aerosols [Andreae, 1983], since the combustion of plant matter, which contains $\mathrm{K}^{+}$as a major electrolyte within its cytoplasm, releases large amounts of K-rich particles in the submicron size fraction [Cachier et al., 1991; Gaudichet et al., 1995]. Contributions of soil- or sea-spray-derived $\mathrm{K}$ in the submicron aerosol are usually minor and can readily be subtracted using the element $\mathrm{Ca}$, which is present in sea salt and crustal materials at about the same concentration as $\mathrm{K}$ [Andreae, 1983]. The $\mathrm{K}$ emission factors for the various fires studied during SAFARI-92 span the range of 0.16$0.44 \mathrm{~g} \mathrm{~kg}^{-1} \mathrm{dm}$ (average $0.36 \pm 0.10 \mathrm{~g} \mathrm{~kg}^{-1} \mathrm{dm}$ ). These values agree well with previous observations, for example, the measurements in West African savannas $\left(0.34 \mathrm{~g} \mathrm{~kg}^{-1} \mathrm{dm}\right)$ and at $\mathrm{KNP}(0.30 \mathrm{~g}$ $\mathrm{kg}^{-1} \mathrm{dm}$ ) by Echalar et al. [1995], and the laboratory burn studies (0.22-0.73 $\mathrm{g} \mathrm{kg}^{-1} \mathrm{dm}$ for various crop and tree residues) by Turn et al. [1997]. The $\mathrm{K}$ emission ratios from SAFARI-92 are somewhat higher than values from chaparral fires in California $(0.26 \mathrm{~g}$ $\mathrm{kg}^{-1} \mathrm{dm}$ [Cofer et al., 1988]), savanna fires in Brazil $\left(0.22 \mathrm{~g} \mathrm{~kg}^{-1}\right.$ $\mathrm{dm}$ [Ward et al., 1992]), and forest fires in the Amazon $(0.11 \mathrm{~g}$ $\mathrm{kg}^{-1} \mathrm{dm}$; [Andreae et al., 1988b]). Our measurements over the Drakensberg forest fires did not show the lower $\mathrm{K}$ emission ratios previously reported from tropical forest fires [Andreae et al., 1988b; Echalar et al., 1995]. This may be due to the dryness of the fuel and the high component of grassy and leafy material in the Drakensberg native forest as compared to the fuels burning in tropical rain forests.

Our emission factors for the major anionic species, $\mathrm{Cl}^{-}, \mathrm{NO}_{3}^{-}$ and $\mathrm{SO}_{4}{ }^{2-}$, are higher than most previously reported values. For chloride we measured $1.4 \pm 0.4 \mathrm{~g} \mathrm{~kg}^{-1} \mathrm{dm}$, significantly higher than the value found for grassy fuels by Turn et al. [1997] $(0.88 \mathrm{~g}$ $\mathrm{kg}^{-1} \mathrm{dm}$ ) and almost a magnitude higher than the values given by Echalar et al. [1995] for the KNP fires $\left(0.28 \mathrm{~g} \mathrm{~kg}^{-1} \mathrm{dm}\right)$ and the fires in the West African savanna $\left(0.22 \mathrm{~g} \mathrm{~kg}^{-1} \mathrm{dm}\right)$. Support for the validity of our high chloride emission ratios comes from the ground-based aerosol measurements of Maenhaut et al. [1996], who measured a chlorine content of $9.7 \%$ in the fine aerosol from the flaming phase of combustion at the KNP fires. Simultaneous ground level measurements of $\mathrm{EF}_{\mathrm{PM} 2.5}$ gave a value of $7.2 \mathrm{~g} \mathrm{~kg}^{-1}$ $\mathrm{dm}$, corresponding to a chloride emission of $0.7 \mathrm{~g} \mathrm{~kg}^{-1} \mathrm{dm}$.

Nitrate has not been commonly measured in pyrogenic aerosols. It is predominantly present in the large size fraction, which is difficult to collect quantitatively and is prone to revolatilization when samples are collected without size fractionation and over prolonged sampling periods. Our nitrate emission factor $\left(0.37 \pm 0.20 \mathrm{~g} \mathrm{~kg}^{-1} \mathrm{dm}\right)$ greatly exceeds the values from laboratory combustion experiments $\left(0.02 \pm 0.01 \mathrm{~g} \mathrm{~kg}^{-1} \mathrm{dm}\right)$. This may be at least in part due to the somewhat higher age of our plumes, which would make additional formation of $\mathrm{HNO}_{3}$ and its deposition to aerosol particles possible. This view is supported by airborne measurements of aerosol nitrate over chaparral fires in southern California [Hegg et al., 1987], which yielded an almost identical nitrate emission factor to ours $\left(0.42 \mathrm{~g} \mathrm{~kg}^{-1} \mathrm{dm}\right)$.

For sulfate, our average of $0.59 \pm 0.24 \mathrm{~g} \mathrm{~kg}^{-1} \mathrm{dm}$ is significantly higher than the ground-based measurements at KNP $\left(0.15 \mathrm{~g} \mathrm{~kg}^{-1}\right.$ $\mathrm{dm})$ and in western Africa $\left(0.06 \mathrm{~g} \mathrm{~kg}^{-1} \mathrm{dm}\right)$ [Echalar et al., 1995]. Since our measurements and those of Echalar et al. [1995] were taken over some of the same fires, closer agreement was expected. The observed differences may be at least in part due to different sampling conditions: Echalar et al. [1995] sampled very close to the fire (meters) where high temperatures and the very short age of the plume would result in partitioning of volatile species into the gas phase. Our airborne samples were collected after some plume aging and at lower temperatures, which would have lead to uptake of additional nitrate and sulfate from gas phase precursors [Gaudichet et al., 1995; Cachier et al., 1996], and to the conden- 
Table 2. Emission Factors for Soluble Ionic Aerosol Species in Gram Species per Kilogram Dry Mass and Elemental Mass Ratios of $\mathrm{K}, \mathrm{Cl}$, and $\mathrm{S}$ to Black Carbon

\begin{tabular}{|c|c|c|c|c|c|c|c|}
\hline Species & $\begin{array}{c}\text { KNP } \\
\text { Block } 56\end{array}$ & $\begin{array}{c}\text { KNP } \\
\text { Block } 55\end{array}$ & $\begin{array}{l}\text { Zambia } \\
\text { Savanna }\end{array}$ & $\begin{array}{l}\text { Sugar } \\
\text { Cane }\end{array}$ & $\begin{array}{c}\text { Subtropical } \\
\text { Forest }\end{array}$ & Average & s.d. \\
\hline Filter samples & 1 & 2 & 1 & 2 & 1 & & \\
\hline $\mathrm{Cl}^{-}$ & 1.04 & 1.06 & 1.76 & 1.75 & -- & 1.40 & 0.35 \\
\hline $\mathrm{NO}_{3}^{-}$ & 0.18 & 0.29 & 0.45 & 0,22 & 0.72 & 0.37 & 0.20 \\
\hline $\mathrm{SO}_{4}^{=}$ & 0.37 & 0.42 & 0.51 & 1.05 & 0.62 & 0.59 & 0.24 \\
\hline$O x=$ & 0.06 & 0.01 & 0.08 & 0.04 & -- & 0.05 & 0.03 \\
\hline $\mathrm{NH}_{4}^{+}$ & 0.34 & 0.18 & 1.13 & 0.42 & -- & 0.52 & 0.36 \\
\hline $\mathrm{K}^{+}$ & 0.44 & 0.16 & 0.38 & 0.43 & 0.41 & 0.36 & 0.10 \\
\hline $\mathrm{Na}^{+}$ & 0.14 & 0.03 & 0.13 & 0.25 & 0.68 & 0.25 & 0.23 \\
\hline $\mathrm{Ca}^{++}$ & 0.29 & 0.11 & - & 0.42 & 0.84 & 0.42 & 0.27 \\
\hline $\mathrm{Mg}^{++}$ & 0.07 & 0.11 & 0.05 & 0.49 & 0.45 & 0.23 & 0.20 \\
\hline K/BC & 1.01 & 0.44 & 0.42 & 0.70 & 1.46 & 0.80 & 0.39 \\
\hline $\mathrm{Cl} / \mathrm{BC}$ & 2.36 & 2.87 & 1.94 & 2.86 & $\ldots$ & 2.51 & 0.39 \\
\hline S/BC & 0.28 & 0.38 & 0.19 & 0.57 & 0.74 & 0.43 & 0.20 \\
\hline
\end{tabular}

sation of species such as $\mathrm{NH}_{4} \mathrm{Cl}$ and $\mathrm{NH}_{4} \mathrm{NO}_{3}$. This explanation is consistent with the high ammonium emission factors $(0.52 \pm 0.36 \mathrm{~g}$ $\mathrm{kg}^{-1} \mathrm{dm}$ ) observed in our study and may also account for the fact that our $\mathrm{NH}_{4}^{+}$emission factors exceed those for $\mathrm{K}^{+}$, in contrast to observations made by others using helicopters as sampling platform [Cofer et al., 1988].

\subsection{Fuel Composition; Release and Recovery Factors}

To examine what fraction of the elemental content of the savanna vegetation was volatilized during combustion (release fraction), and what fraction was recovered as aerosol particles, we analyzed the preburn fuel and the postfire ash and char from the two large KNP fires (Table 3). The biomass composition was based on the analysis of 12 samples from the KNP savannas (sites at Naapi, Kambeni, Shabeni, blocks 55 and 56) by instrumental neutron activation, except for the carbon, nitrogen, and sulfur concentrations, which were taken from Kuhlbusch et al. [1996]. The standard deviations of the fuel composition data are typically in the range of $20-50 \%$, representing the high variability of the elemental content of the various biomass types.

The release fractions were calculated for each element by summing the amounts of the element present in the various fuel residue components (i.e., unburned fuel, charred fuel, and ash) on $1 \mathrm{~m}^{2}$ and then subtracting this value from the element content of the original fuel. The release fraction is then obtained by dividing this difference (which represents the amount of element released by combustion) by the original element content of the fuel. Table 3 shows that the release fraction varies over a wide range, from near zero for elements like $\mathrm{Fe}, \mathrm{Ni}, \mathrm{Sc}$, and $\mathrm{Ti}$ to almost $90 \%$ for $\mathrm{C}, \mathrm{Cl}$, and $\mathrm{Br}$. Most of the soluble but involatile elements (e.g., $\mathrm{Mg}, \mathrm{Na}, \mathrm{K}, \mathrm{Ca}, \mathrm{Zn}$, etc.), which would be present in the cytoplasm in moist plant tissues, or as finely dispersed salt crystals in dry plant material, show intermediate release fractions around $50 \%$.

From these release fractions we can derive a release factor (the product of the fuel element content and the release fraction), which represents the amount of element removed from the site during combustion. This value can be compared with the aerosol emission factor obtained by our airborne measurements or by the ground-based measurements detailed by Maenhaut et al. [1996] We term the ratio between the emission and the release factors "aerosol recovery"; this value indicates how much of the amount of an element released during the fire is recovered in particulate form. This number is very small in the case of carbon (0.5-1.0\%), which is not surprising because most carbon is emitted as $\mathrm{CO}_{2}$, $\mathrm{CO}$, and hydrocarbons. Small aerosol recoveries (about 3-6\%) are also obtained for $\mathrm{N}$ and $\mathrm{S}$, where again most of the emissions are in gaseous form. In contrast, the halogen elements are recovered to $60-95 \%$ in the aerosol, suggesting that gaseous hydrogen halides are very rapidly taken up by the smoke aerosol. The aerosol recoveries of most of the soluble elements are surprisingly low, in the range of $10-25 \%$. The unrecovered fraction must represent coarse ash particles, which can remain airborne long enough that they are not redeposited close to their emission site and, consequently, are not found in the ash samples collected on the ground but which are too coarse to be transported up to the sampling altitude of the aircraft or to be efficiently collected by our samplers, which experience inlet losses in the particle size range above $\sim 5$ $\mu \mathrm{m}$. Where emission factors were determined both from aircraft and at the ground, there are noticeable differences between the two measurements (Table 3). While higher emission ratios are observed at the ground for species directly related to combustion, such as organic carbon and potassium, the elements related to mineral dust $(\mathrm{Na}, \mathrm{Mg}$, and $\mathrm{Ca}$ ) show higher emission ratios in the aircraft samples. This may be related to differences in the fire regime sampled by the two techniques. Ground sampling is restricted to less intense regions of the fire, where combustion is less efficient, and higher amounts of organic aerosols are produced, while the smoke sampled by aircraft would be preferentially from the most vigorous parts of the fire, where combustion 
Table 3. Fuel Element Budget for the KNP Savanna Fires

\begin{tabular}{|c|c|c|c|c|c|}
\hline Element & $\begin{array}{l}\text { Fuel Composition } \\
\mathrm{mg} \mathrm{kg}^{-1}\end{array}$ & $\begin{array}{c}\text { Release Fraction } \\
\%\end{array}$ & $\begin{array}{l}\text { Release Factor } \\
\mathrm{mg} \mathrm{kg}^{-1}\end{array}$ & $\begin{array}{c}\text { Emission } \\
\text { Factor } \\
\mathrm{mg} \mathrm{kg}^{-1}\end{array}$ & $\begin{array}{c}\text { Aerosol Recovery } \\
\%\end{array}$ \\
\hline $\bar{C}$ & $480000 \pm 14000$ & 88 & 422000 & $2000^{2}-7000^{b}$ & $0.5-1.7$ \\
\hline $\mathbf{N}$ & $5700 \pm 1100$ & 74 & 4200 & $260^{\mathrm{a}}$ & 6.2 \\
\hline $\mathbf{N a}$ & $845 \pm 460$ & $42 \pm 15$ & 350 & $46^{b}-90^{a}$ & $13-26$ \\
\hline $\mathbf{M g}$ & $1610_{ \pm 480}$ & $55 \pm 3$ & 885 & $22^{b}-90^{a}$ & $2.5-10.2$ \\
\hline $\mathrm{Al}$ & $2610 \pm 1150$ & $21 \pm 7$ & 548 & $61^{b}$ & 11.1 \\
\hline $\mathbf{s}$ & $2100 \pm 400$ & 86 & 1810 & $53^{b}-117^{a}$ & $2.9-6.5$ \\
\hline $\mathrm{Cl}$ & $1260 \pm 310$ & $88 \pm 0.5$ & 1110 & $650^{\mathrm{b}}-1050^{\mathrm{a}}$ & $59-95$ \\
\hline $\mathbf{K}$ & $4810 \pm 1110$ & $56 \pm 3$ & 2700 & $300^{\mathrm{a}}-450^{\mathrm{b}}$ & $11-17$ \\
\hline $\mathrm{Ca}$ & $6030 \pm 2235$ & $69 \pm 2$ & 4160 & $89^{b}-200^{2}$ & 4.8 \\
\hline Sc & $0.22 \pm 0.11$ & $(-6 \pm 22)$ & $<0.04$ & $0.01^{b}$ & 25 \\
\hline $\mathrm{Ti}$ & $173 \pm 53$ & $1.3 \pm 0.0$ & 2.25 & $3.7^{b}$ & (165) \\
\hline $\mathrm{v}$ & $2.9 \pm 1.3$ & $21 \pm 20$ & $<0.6$ & $0.11^{b}$ & $>20$ \\
\hline $\mathrm{Cr}$ & $133 \pm 36$ & $16 \pm 14$ & 21.3 & $5.9^{\mathrm{b}}$ & 28 \\
\hline Mn & $166 \pm 46$ & $55 \pm 13$ & 91.3 & $3.6^{\mathrm{b}}$ & 3.9 \\
\hline $\mathrm{Fe}$ & $1450 \pm 450$ & $0 \pm 4$ & $<60$ & $26^{b}$ & $>43$ \\
\hline Co & $2.0 \pm 0.5$ & $9 \pm 18$ & 0.18 & -- & $\cdots$ \\
\hline $\mathbf{N i}$ & $60 \pm 17$ & $1 \pm 28$ & 0.6 & -- & $\ldots$ \\
\hline $\mathrm{Zn}$ & $20 \pm 5$ & $47 \pm 5$ & 9.4 & $3.2^{\mathrm{b}}$ & 34 \\
\hline As & $0.19 \pm 0.03$ & $23 \pm 19$ & 0.04 & $<0.05^{b}$ & $\cdots$ \\
\hline $\mathrm{Se}$ & $0.25 \pm 0.08$ & $71 \pm 8$ & 0.18 & $<0.8^{\mathrm{b}}$ & -- \\
\hline $\mathrm{Br}$ & $7.0 \pm 1.6$ & $88 \pm 3$ & 6.16 & $4.8^{b}$ & 78 \\
\hline $\mathbf{R b}$ & $5.8 \pm 1.6$ & $38 \pm 4$ & 2.2 & $0.4^{\mathrm{b}}$ & 18 \\
\hline Sr & $111 \pm 48$ & $73 \pm 10$ & 81 & $1.4^{\mathrm{b}}$ & 1.7 \\
\hline Mo & $9.3 \pm 2.6$ & $6 \pm 34$ & 0.56 & $0.016^{b}$ & 2.9 \\
\hline Sb & $0.10 \pm 0.02$ & $45 \pm 5$ & 0.045 & $0.016^{b}$ & 36 \\
\hline I & $1.3 \pm 0.3$ & $65 \pm 11$ & 0.85 & $0.77^{b}$ & 91 \\
\hline Cs & $0.064 \pm 0.019$ & $20 \pm 8$ & 0.013 & $0.044^{b}$ & (340) \\
\hline $\mathbf{B a}$ & $118 \pm 41$ & $58 \pm 11$ & 68 & $\cdots$ & -- \\
\hline $\mathrm{La}$ & $3.8 \pm 1.8$ & $56 \pm 10$ & 2.1 & $0.095^{b}$ & 4.5 \\
\hline $\mathrm{Au}$ & $0.0021 \pm 0.0017$ & $61 \pm 16$ & 0.0013 & $0.0013^{b}$ & 100 \\
\hline Th & $0.39 \pm 0.16$ & $17 \pm 10$ & 0.066 & - & -- \\
\hline
\end{tabular}

The release fraction is computed from the relation between fuel and residue composition and the release factor from the release fraction and the amount of biomass burned. Aerosol recovery is the ratio between aerosol emission factors and release factors.

2) From airborne measurements.

b) From ground-based measurements reported by Maenhaut et al. [1996].

is more efficient and more dust can be entrained because of the strong turbulence generated by the fire.

\section{Summary and Conclusions}

From in-flight measurements and samples collected during the SAFARI-92 flight campaign we determined the chemical composition of the smoke aerosols and the corresponding emission factors from vegetation fires in southern Africa. Such fires represent typical agricultural and range management practices in the region and have been shown to have a pronounced influence on regional and even global atmospheric composition. Organic and black carbon made up a large fraction of the smoke aerosol. The BC content of the aerosol was unusually high $(-10-30 \%)$, which is probably due to the very effective flaming combustion of the dry grassy material that made up most of the fuel in the savanna and grassland fires. The high $\mathrm{BC}$ content of the smoke results in a high light absorption coefficient of the aerosol, which was often visually evident as a dark coloration of the smoke plumes. This may have important consequences for the climatic effects of aerosols from savanna fires [Hansen et al., 1997].

In the soluble ionic aerosol fraction, chloride was the most abundant anion. The chloride concentrations and emission factors were higher than previously reported, which may be related to the relatively high halogen content of the semiarid vegetation in the study region [McKenzie et al., 1996]. Sulfate was the second largest contributor to the anionic component, followed by nitrate. Nitrate was present almost exclusively in the coarse aerosol fraction, suggesting absorption of $\mathrm{HNO}_{3}$ on mineral aerosol particles. $\mathrm{NH}_{4}^{+}$and $\mathrm{K}^{+}$at about equal concentrations dominated the cation component of the fine aerosol. This observation is in accord with previous suggestions that $\mathrm{NH}_{3}$ accounts for a significant fraction of the nitrogen emitted from biomass fires [Andreae et al., 1996a] and may be important in the nutrient budget of ecosystems subject to fires. In the coarse fraction, calcium and magnesium were abundant, especially over very vigorous fires that create strong turbulence.

From measurements of the difference between the element 
content of the fuel and the residues left after the fire, we derived, for a large number of chemical elements, the fraction of the element mobilized during the combustion process as gas or aerosol species (release fraction). We found that elements associated with soil minerals are not mobilized efficiently, while $\mathrm{C}, \mathrm{N}, \mathrm{S}$, and the halogens are released almost completely. Elements that are associated with the cytoplasm of plants (e.g., $\mathrm{Mg}, \mathrm{Na}, \mathrm{K}, \mathrm{Ca}, \mathrm{Zn}$, etc.) showed intermediate release fractions.

From the release fraction and the amount of biomass burned we calculated "release factors," i.e., the amount of material lost from the vegetation during combustion. When comparing these values to the aerosol emission factors determined at the ground or from aircraft, we found highly variable "recoveries" in the aerosol. For those elements that form stable gaseous species, such as $\mathrm{C}, \mathrm{N}$, and $\mathrm{S}$, only a small fraction of the element released was found in the aerosol, as would be expected for the fresh plumes studied here. On the other hand, the halogen elements were recovered almost completely in the aerosol, suggesting rapid absorption of the hydrogen halides or condensation of ammonium halides.

In several respects, our measurements pointed to substantial differences between observations made at the ground and from aircraft. This may be partially related to some instrumental effects, such as the different size cutoffs of intakes, etc. The fact that ground-based sampling is limited to the less vigorous parts of a fire may also play a role. However, our data also suggest that relatively rapid changes may take place due to transfer between gas phase and aerosol, such as volatilization of some of the organic components and deposition of $\mathrm{HNO}_{3}$ and hydrogen halides.

Acknowledgments. We thank the pilots and crews of the SAFARI-92 research aircraft for their assistance during the research flights, the Kruger Park team (particularly A. Potgieter, W. Trollope, L. Trollope, and J. $\mathrm{G}$. Goldammer) for their untiring cooperation during the experimental fires in the park, and the team at the sugar plantation at Ubombo Ranches, Big Bend, Swaziland, (especially J. Gosnell and D. Shipley) for their generous help dunng our experiment. We acknowledge the permission of various government agencies in Angola, Botswana, South Africa, Namibia, Swazıland, Zambia, and Zimbabwe for permıssion to conduct research in these countries or to use the airspace over these countries. We appreciate the technical support of U. Parchatka during the airborne sampling missions on the DC-3 aircraft. This research is a contribution to the International Global Atmospheric Chemistry (IGAC) core project of the International Geosphere-Biosphere Programme (IGBP) and is part of the IGAC Biomass Burning Experiment (BIBEX). W.M. is indebted to the Belgian Federal Office for Scientific, Technical and Cultural Affairs and the „Fonds voor Wetenschappelijk Onderzoek - Vlaanderen“ for research support. This research was supported by the German Max Planck Society.

\section{References}

Allen, A. G., and A. H. Miguel, Biomass burning in the Amazon: Charactenzation of the ionic components of aerosols generated from flaming and smoldering rain forest and savannah, Environ. Sci. Technol., $29,486-493,1995$.

Andreae, M. O., Soot carbon and excess fine potassium: Long-range transport of combustion-derived aerosols, Science, 220, 1148-1151, 1983.

Andreae, M. O., Global distribution of fires seen from space, Eos Trans. $A G U, 74(12), 129-135,1993 \mathrm{a}$.

Andreae, M. O., The influence of tropical biomass burning on climate and the atmospheric environment, in Biogeochemistry of Global Change: Radiatively Active Trace Gases, edited by R. S. Oremland, pp. 113-150, Chapman and Hall, New York, 1993b.

Andreae, M. O., Climatic effects of changing atmospheric aerosols levels, in World Survey of Climatology, vol. 16, Future Climates of the World, edited by A. Henderson-Sellers, pp. 341-392, Elsevier, New York, 1995.

Andreae, M. O., and P. J. Crutzen, Atmospheric aerosols: Biogeochemi- cal sources and role in atmospheric chemistry, Science, 276, 10521056, 1997.

Andreae, M. O., H. Berresheim, T. W. Andreae, M. A. Kritz, T. S. Bates, and J. T. Merrill, Vertical distribution of dimethylsulfide, sulfur dioxide, aerosol ions, and radon over the northeast Pacific Ocean, J. Atmos. Chem., 6, 149-173, 1988a.

Andreae, M. O., et al., Biomass-burning emissions and associated haze layers over Amazonia, J. Geophys. Res., 93, 1509-1527, 1988b.

Andreae, M. O. et al., Biomass burning in the global environment: First results from the IGAC/BIBEX field campaign STARE/TRACEA/SAFARI-92, in Global Atmospheric-Biospheric Chemistry, edited by R. G. Prinn, pp. 83-101, Plenum, New York, 1994.

Andreae, M. O., E. Atlas, H. Cachier, W. R. Cofer III, G. W. Harris, G. Helas, R. Koppmann, J.-P. Lacaux, and D. E. Ward, Trace gas and aerosol emissions from savanna fires, in Biomass Burning and Global Change, edited by J. S. Levine, pp. 278-295, MIT Press, Cambridge, Mass., 1996a.

Andreae, M. O., J. Fishman, and J. Lindesay, The Southern Tropical Atlantic Region Experiment (STARE): Transport and Atmospheric Chemistry near the Equator - Atlantic (TRACE-A) and Southern African Fire/Atmosphere Research Initiative (SAFARI): An introduction, J. Geophys. Res., 101, 23,519-23,520, 1996b.

Beck, W., and H. Engelhardt, Capillary electrophoresis of organic and inorganic cations with indirect UV detection, Chromatographia, 33, 313-316, 1992.

Cachier, H., J. Ducret, M.-P. Brémond, V. Yoboué, J.-P. Lacaux, A. Gaudichet, and $\mathrm{J}$. Baudet, Biomass burning in a savanna region of the Ivory Coast, in Global Biomass Burning: Atmospheric, Climatic and Biospheric Implications, edited by J. S. Levine, pp. 174-180, MIT Press, Cambridge, Mass., 1991.

Cachier, H., C. Liousse, P. Buat-Menard, and A. Gaudichet, Particulate content of savanna fire emissions, J. Atmos. Chem., 22, 123-148, 1995.

Cachier, H., C. Liousse, M.-H. Pertuisot, A. Gaudichet, F. Echalar, and J.-P. Lacaux, African fire particulate emission and atmospheric influence, in Biomass Burning and Global Change, edited by J. S. Levine, pp. 428-440, MIT Press, Cambridge, Mass., 1996.

Charlson, R. J., J. E. Lovelock, M. O. Andreae, and S. G. Warren, Oceanic phytoplankton, atmospheric sulphur, cloud albedo, and climate, Nature, 326, 655-661, 1987.

Charlson, R J., S. E. Schwartz, J. M. Hales, R. D. Cess, J. A. Coakley, J. E. Hansen, and D. J. Hofmann, Climate forcing by anthropogenic aerosols, Science, 255, 423-430, 1992.

Cofer, W. R. III, J. S. Levine, D. I. Sebacher, E. L. Winstead, P. J. Riggan, J. A. Brass, and V. G. Ambrosia, Particulate emissions from a mid-latitude prescribed chaparral fire, J. Geophys. Res., 93, 5207$5212,1988$.

Cofer, W. R. III, J. S. Levine, E. L. Winstead, D. R. Cahoon, D. I. Sebacher, J. P. Pinto, and B. J. Stocks, Source composition of trace gases released during African savanna fires, J. Geophys. Res., 10I, 23,597-23,602, 1996.

Echalar, F., A. Gaudichet, H. Cachier, and P. Artaxo, Aerosol emissions by tropical forest and savanna biomass burning: Characteristic trace elements and fluxes, Geophys. Res. Lett., 22, 3039-3042, 1995.

Echalar, F., P. Artaxo, J. V. Martins, M. A. Yamasoe, F. Gerab, W. Maenhaut, and B. Holben, Long-term monitoring of atmospheric aerosols in the Amazon Basin: source identification and apportionment, $J$. Geophys. Res., this issue.

Ferek, R. J., J. S. Reid, P. V. Hobbs, D. Blake, and C. Liousse, Emission factors of hydrocarbons, halocarbons, trace gases, and particles from biomass burning in Brazil, J. Geophys. Res., this issue.

Garstang, M., P. D. Tyson, E. Browell, and R. J. Swap, Large scale transport of biogenic and biomass burning products, in Biomass Burning and Global Change, edited by J. S. Levine, pp. 389-395, MIT Press, Cambridge, Mass., 1996.

Gaudichet, A., F. Echalar, B. Chatenet, J. P. Quisefit, G. Malingre, H. Cachier, P Buat-Ménard, P. Artaxo, and W. Maenhaut, Trace elements in tropical African savanna biomass burning aerosols, J. Atmos. Chem., 22, 19-39, 1995.

Hansen, J., M. Sato, and R. Ruedy, Radiative forcing and climate response, J. Geophys. Res., 102, 6831-6864, 1997.

Hao, W.-M., and M.-H. Liu, Spatial and temporal distribution of tropical biomass burning, Global Biogeochem. Cycles, 8, 495-503, 1994.

Hegg, D. A., L. F. Radke, P. V. Hobbs, C. A. Brock, and P. J. Riggan, Nitrogen and sulfur emissions from the burning of forest products near large urban areas, J. Geophys. Res., 92, 14,701-14,709, 1987. 
Houghton, J. T., L. G. Meira Filho, B. A. Callander, N. Harris, A. Kattenberg, and K. Maskell (Eds.), Climate Change, 1995: The Science of Climate Change, 572 pp., Cambridge University Press, New York, 1996.

John, W., S. Hering, G. Reischl, G. Sasaki, and S. Goren, Characteristics of Nuclepore filters with large pore size, II, Filtration properties, At mos. Environ., 17, 373-382, 1983.

Kaufman, Y. J., et al., Smoke, Clouds, and Radiation-Brazil (SCAR-B) experiment, J. Geophys. Res., this issue.

Kirchhoff, V. W. J. H., E. V. A. Marinho, P. L. S. Dias, E. B. Pereira, R. Calheiros, R. André, and C. Volpe, Enhancements of $\mathrm{CO}$ and $\mathrm{O}_{3}$ from burnings in sugar cane fields, J. Atmos. Chem., 12, 87-102, 1991.

Kuhlbusch, T. A. J., M. O. Andreae, H. Cachier, J. G. Goldammer, J.-P. Lacaux, R. Shea, and P. J. Crutzen, Black carbon formation by savanna fires: Measurements and implications for the global carbon cycle, J. Geophys. Res., 101, 23,651-23,665, 1996.

Lacaux, J. P., J. M. Brustet, R. Delmas, J. C. Menaut, L. Abbadie, B. Bonsang, H. Cachier, J. Baudet, M. O. Andreae, and G. Helas, Biomass burning in the tropical savannas of Ivory Coast: An overview of the field experiment Fire of Savannas (FOS/DECAFE '91), J. Atmos. Chem., 22, 195-216, 1995.

Le Canut, P., M. O. Andreae, G. W. Harris, F. G. Wienhold, and T. Zenker, Aerosol optical properties over southern Africa during SAFARI92, in Biomass Burning and Global Change, edited by J. S. Levine, pp. 441-459, MIT Press, Cambridge, Mass., 1996a.

Le Canut, P., M. O. Andreae, G. W. Harris, F. G. Wienhold, and T. Zenker, Airborne studies of emissions from savanna fires in southern Africa, 1. Aerosol emissions measured with a laser optical particle counter, J. Geophys. Res., 101, 23,615-23,630, $1996 \mathrm{~b}$.

Liousse, C., H. Cachier, and S. G. Jennings, Optical and thermal measurements of black carbon aerosol content in different environments Variation of the specific attenuation cross-section, sigma (s), Atmos. Environ., 27A, 1203-1211, 1993.

Liousse, C., C. Devaux, F. Dulac, and H. Cachier, Aging of savanna biomass buming aerosols: Consequences on their optical properties, $J$. Atmos. Chem., 22, 1-17, 1995.

Liousse, C , J. E. Penner, J. J. Walton, H. Eddleman, C. Chuang, and H Cachier, Modeling biomass burning aerosols, in Blomass Burning and Global Change, edited by J, S. Levine, pp. 492-508, MIT Press, Cambridge, Mass., 1996.

Maenhaut, W., I. Salma, J. Cafmeyer, H. J. Annegarn, and M. O. Andreae, Regional atmospheric aerosol composition and sources in the eastern Transvaal, South Africa, and impact of biomass burning, $J$. Geophys. Res., 101, 23,631-23,650, 1996.

McKenzie, L. M., D. E. Ward, and W.-M. Hao, Chlorine and bromine in the biomass of tropical and temperate ecosystems, in Biomass Burning and Global Change, edited by J. S. Levine, pp. 241-248, MIT Press, Cambridge, Mass., 1996.

Novakov, T., and C. E. Corrigan, Cloud condensation nucleus activity of the organic component of biomass smoke particles, Geophys. Res. Lett., 23, 2141-2144, 1996.

Pereira, E. B., A. W. Setzer, F. Gerab, P. E. Artaxo, M. C. Pereira, and G. Monroe, Airborne measurements of aerosols from burning biomass in Brazil related to the TRACE-A experiment, J. Geophys. Res., 101, 23,983-23,992, 1996.

Pszenny, A. A. P., and R. G. Prinn (Eds.), International Global Atmospheric Chemistry (IGAC) Project: The Operational Plan, Global Change Rep. 32, 134 pp., Int. Geos.-Bios. Programme, Stockholm, 1994

Reld, J. S., P. V. Hobbs, R. J. Ferek, D. R. Blake, J. V. Martins, M. Dunlop, and C. Liousse, Physical, chemical, and optical properties of regional hazes dominated by smoke in Brazil, J. Geophys. Res., this issue.

Schutyser, P., W. Maenhaut, and R. Dams, Instrumental neutron activation analysis of dry atmospheric fall-out and rainwater, Anal. Chem. Acta, 100, 75-85, 1978.

Shea, R. W., B. W. Shea, J. B. Kauffman, D. E. Ward, C. I. Haskins, and M. C. Scholes, Fuel biomass and combustion factors associated with fires in savanna ecosystems of South Africa and Zambia, J. Geophys. Res., 101, 23,551-23,568, 1996
Stocks, B. J., B. W. van Wilgen, W. S. W. Trollope, D. J. McRae, J. A Mason, F. Weirich, and A. L. F. Potgieter, Fuels and fire behavior dy namics on large-scale savanna fires in Kruger National Park, South Africa, J. Geophys. Res., 101, 23,541-23,550, 1996.

Susott, R. A., G. J. Olbu, S. P. Baker, D. E. Ward, J. B. Kauffman, and R. W. Shea, Carbon, hydrogen and nitrogen, and thermogravimetric analysis of tropical ecosystem biomass, in Biomass Burning and Global Change, edited by J. S. Levine, pp. 249-259, MIT Press, Cambridge, Mass., 1996.

Thompson, A. M., K. E. Pickering, D. P. McNamara, M. R. Schoeberl, R. D. Hudson, J.-H. Kim, E. V. Browell, V. W. J. H. Kirchhoff, and D. Nganga, Where did tropospheric ozone over southern Africa and the tropical Atlantic come from in October 1992?, Insights from TOMS, GTE TRACE-A, and SAFARI 1992, J. Geophys. Res., 101, 24,25124,278, 1996

Trollope, W. S. W., L. A. Trollope, A. L. F. Potgieter, and N. Zambatis, SAFARI-92 characterization of biomass and fire behavior in the small experimental burns in the Kruger National Park, J. Geophys. Res. 101, 23,531-23,540, 1996.

Turn, S. Q., B. M. Jenkins, J. C. Chow, L. C. Pritchett, D. Campbell, T. Cahill, and S. A. Whalen, Elemental characterization of particulate matter emitted from biomass buming, Wind tunnel derived source profiles for herbaceous and wood fuels, J. Geophys. Res., 102, 36833699, 1997.

Ward, D. E., A. W. Setzer, Y. J. Kaufman, and R. A. Rasmussen, Characteristics of smoke emissions from biomass fires of the Amazon region BASE-A experiment, in Global Biomass Burning: Atmospheric, Climatic, and Biospheric Implications, edited by J. S. Levine, pp. 394-402, MIT Press, Cambridge, Mass., 1991.

Ward, D. E., R. A. Susott, J. B. Kauffman, R. E. Babbitt, D. L. Cummings, B. Dias, B. N. Holben, Y. J. Kaufman, R. A. Rasmussen, and A. W. Setzer, Smoke and fire characteristics for cerrado and deforestation burns in Brazil: BASE-B experiment, J. Geophys. Res., 97, 14,601-14,619, 1992.

Ward, D. E., W.-M. Hao, R. A. Susott, R. A. Babbitt, R. W. Shea, J. B. Kauffman, and C. O. Justice, Effect of fuel composition on combustion efficiency and emission factors for African savanna ecosystems. J. Geophys. Res., 101, 23,569-23,576, 1996.

Zenker, T., A. M. Thompson, D. P. McNamara, T. L. Kuscera, G. W. Harris, F. G. Wienhold, P. le Canut, M. O. Andreae, and R. Koppmann, Regional trace gas distribution and air mass characteristics in the haze layer over southern Africa during the biomass burning season (Sep./Oct. 92): Observations and modeling from the STARE/SAFARI'92/DC-3, in Biomass Burning and Global Change, edited by J. S. Levine, pp. 296-308, MIT Press, Cambridge, Mass., 1996.

M. O. Andreae, T. W. Andreae, and W. Elbert, Department of Biogeochemistry, Max Planck Institute for Chemistry, P.O. Box 3060, D-55020 Mainz, Germany. (e-mail:moa@mpch-mainz.mpg.de)

P. Le Canut, 1, rue Verte, F-14760 Bretteville/Odon, France.

F. G. Wienhold, Fraunhofer Institut für Physikalische MeBtechnik, Heidenhofstr. 8, D-79110 Freiburg, Germany.

T. Zenker, Atmospheric Sciences Division, NASA Langley Research Center, Mail Stop 401-A, Hampton, VA 23681.

H. Annegarn and J. Beer, Schonland Research Centre for Nuclear Sciences, University of Witwatersrand, Johannesburg, South Africa.

H. Cachier, Centre des Faibles Radioactivités, CNRS-CEA, Gif-surYvette, France.

W. Maenhaut, Institute for Nuclear Sciences, University of Gent, Proeftuinstraat 86, B-9000 Gent, Belgium.

I. Salma, KFKI Atomic Energy Research Institute, P.O. Box 49, H-1525

Budapest, Hungary. (e-mail: salma @ sunserv.kfki.hu)

(Received March 10, 1998; revised July 1, 1998; accepted July 8, 1998) 